\title{
Numerical flow model stepped spillways in order to maximize energy dissipation using FLUENT software
}

\author{
Moussa Rassaei ${ }^{1}$, Sedigheh Rahbar ${ }^{2}$ \\ ${ }^{1}$ Islamic Azad University Dehdasht branch, Iran \\ ${ }^{2}$ Islamic Azad University yasuj branch, Iran
}

\begin{abstract}
Stepped spillway energy dissipation has a synergistic effect. In the present study, to identify, the effect of various parameters such as the number of steps $(\mathrm{N})$, the step height $(\mathrm{h})$, the length step $(\mathrm{L})$ and the discharge per unit width (q) on energy dissipation in stepped spillways simple numerical is used numerical method. Relationshipships between the critical depth flow and energy dissipation are presented and discussed in stepped spillways. In this study for solving the governing equations detachable, the finite volume method (Fluent Software) and to assess turbulence flow, is used the standard k- $\varepsilon$ models. The regular mesh, is used in a Specified boundary condition and the volume of fluid method (VOF) is used to solve the free-surface flow. Free surface flow,Velocities and pressures in stepped spillway, is modeling by Confused numerical method. The numerical results were compared with Experimental results of other researchers, and the results are a good agreement and the errors Variations is one of the $2 \%$. The results of this study show that with increasingthe flow rate and also by fixed dam height and with increasing the number of steps, is reduced energy dissipation.
\end{abstract}

Keywords: - stepped spillway, FLUENT numerical model, turbulence model $k-\varepsilon$, volume of fluid (VOF) model

\section{INTRODUCTION}

The Stepped spillway consists of steps that starts of near spillway crest and continues downstream heels. The use of a stepped spillway, has been common since ancient times. But, because of the significant impact of steps, on the energy dissipation flow, in recent years, due to this type of Spillways has been greater. Also, understanding new technologies, the use of Materials, Roller compact Concrete and consistent the manufacturing method with spillway mentioned, make use of stepped Spillways has a large number of projects. Stepped spillway, is a hydraulic structures, very powerful of Climactic spillway in Amortize the flow energy and reduce erosion downstream of the dams. When the water flow by spillway from the reservoir to water surface in downstream, to falls, the potential energy is converted to kinetic energy. This energy, in the form high-speed in downstream is appears, that, for the prevention of river erosion in downstream, is necessary to install facilities such as Stepped spillways, is amortized. The rate of High energy dissipation, established by the Steps, the caused Drilling deep stilling basin downstream, length of stilling basin and height of the side walls, dropped and this point of view, great savings comes into operation. Salmasi In 1382, calculated and evaluated the reat of energy dissipation in stepped spillways for every steps different by using of experimental work, and showed that, Calculating the energy dissipation in downstream, by using of water depth After the hydraulic jump, to reality is nearer and more accurate [1]. Naderi Rad in 1386 by using of FLUENT numerical model, calculated the energy dissipation in types of simple stepped spillways, edges and Slopes [2]. Spalding and laundr in (1972) the first people who offered the k- $\varepsilon$ model [3]. Christodoulou in 1993, offered method for calculated energy dissipation in stepped spillway by continuous flow [4]. Chamani \& Rajatnam in 1994, offered method, for investigate the rate of energy dissipation in nappe flow regime [5]. James and Partners in 2001, offered a new model for Steps of stepped spillway. in this new model, has been made the edge of steps in the form (V) [6]. Chen and Partners in 2002, analyzed flow over the stepped spillway, by using of the finite-volume method, and the k- $\varepsilon$ model, used to determine turbulence flow [7]. Boes and Hager in 2003, offered an algorithm to calculate the residual energy and not depreciated in stepped spillway. All of these relationshipships are based on experimental works [8]. Chatila and Tabbara in 2004, analyzed Climactic spillway by using the finite element method and the k- $\varepsilon$ model used to determine turbulence flow in the Climactic spillway [9]. Tabbara and Partners in 2005, were analyzed the stepped spillway by using the finite element method and the K$\varepsilon$ model have benefited to determine turbulence flow in the stepped spillway [10]. In this research, is used of the Fluent numerical model, which it works based on the finite volume method and for determination the free surface flow has been used the volume of fluid method (VOF) and for the turbulence flow has been used of the standard K- $\varepsilon$ model. And the continue energy dissipation were calculated on per number of steps 5 th and 10th and compared with experimental results of other researchers, and calculated the error rate and will be discussed performance of the FLUENT model. 


\section{MATERIALS AND MethODS}

\subsection{THEORETICAL RESEARCH}

\subsubsection{TYPES OF FLOW IN STEPPED SPILLWAYS}

2.1.1.1 NAPPE Flow REgime: The flow, that which free jet, Collision of the upper step, to lower step. This type of flow, occurs in low Discharge and high-tall steps. (Fig 1.)

2.1.1.2 Skimming Flow Regime: In the Skimming Flow Regime, steps act such as big coarseness against the flow. (Fig 2.)

2.1.1.3 TRANSITIONAL FLOW REGIME: If the crossing flow over the stepped spillways with slop and Arbitrary number of steps , at low Discharge a stat is falling, Gradually, then Discharge is increased, a case is observed, at the boundary between two Flow the Skimming and Nappe and the conversion threshold is, to Skimming Flow Regime, that this type of flow, is called transitional flow regime

\subsection{THE GOVERNING EQUATIONS FOR THE FLOW}

The incompressible fluid flow, continuity equation and momentum equation is expressed as follows:

$$
\begin{aligned}
& \frac{\partial \mathrm{u}_{\mathrm{i}}}{\partial \mathrm{x}_{\mathrm{j}}} \\
& \frac{\partial \mathrm{pu}_{\mathrm{i}}}{\partial \mathrm{t}}+\frac{\partial}{\partial \mathrm{x}_{\mathrm{j}}}\left(\mathrm{pu}_{\mathrm{j}} \mathrm{u}_{\mathrm{i}}\right)=-\frac{\partial \mathrm{p}}{\partial \mathrm{x}_{\mathrm{i}}}+\frac{\partial}{\partial \mathrm{x}_{\mathrm{j}}}\left[\left(\mu+\mu_{\mathrm{t}}\right)\left\langle\frac{\partial \mathrm{u}_{\mathrm{i}}}{\partial \mathrm{x}_{\mathrm{j}}}+\frac{\partial u_{j}}{\partial \mathrm{x}_{\mathrm{i}}}\right\rangle\right]
\end{aligned}
$$

In which (t) is time, (ui) velocity component, (xi) coordinates component, $(\rho)$ the density, $(\mu)$ the dynamic viscosity, $(\mu \mathrm{t})$ the turbulent viscosity, $\left(\mathrm{p}^{\prime}\right)$ is the pressure corrected , is obtained the following equations.

$$
\mathrm{p}^{\prime}=\mathrm{p}+\frac{2 \mathrm{pk}}{3}
$$

In which $(\mathrm{P})$ is the pressure and $(\mathrm{K})$ is the kinetic energy of perturbation.

Also $\mathrm{K}$ and $\varepsilon$ equations are expressed as follows:

$$
\begin{aligned}
& \frac{\partial(\rho \mathrm{k})}{\partial \mathrm{t}}+\frac{\partial\left(\mathrm{u}_{\mathrm{i}} \mathrm{k}\right)}{\partial \mathrm{x}_{\mathrm{i}}}=\frac{\partial}{\partial \mathrm{x}_{\mathrm{i}}}\left[\left(\mu+\frac{\mu_{\mathrm{t}}}{\sigma_{\mathrm{k}}}\right) \frac{\partial \mathrm{k}}{\partial \mathrm{x}_{\mathrm{i}}}\right]+\mathrm{G}+\rho \varepsilon \\
& \frac{\partial(\rho \varepsilon)}{\partial \mathrm{t}}+\frac{\partial\left(\mathrm{u}_{\mathrm{i}} \varepsilon\right)}{\partial \mathrm{x}_{\mathrm{i}}}=\frac{\partial}{\partial \mathrm{x}_{\mathrm{i}}}\left[\left(\mu+\frac{\mu_{\mathrm{t}}}{\sigma_{\varepsilon}}\right) \frac{\partial \varepsilon}{\partial \mathrm{x}_{\mathrm{i}}}\right]+\mathrm{C}_{1 \varepsilon} \frac{\varepsilon}{\mathrm{K}} \mathrm{G}-\mathrm{C}_{2 \varepsilon} \rho \frac{\varepsilon^{2}}{\mathrm{~K}}
\end{aligned}
$$

In which $(\mu \mathrm{t})$ is the turbulence viscosity by $(\mathrm{k})$ kinetic energy of turbulence and $(\varepsilon)$ the rate of energy dissipation of turbulence is obtained from the following relationshipship

$$
\mu_{\mathrm{t}}=\rho c_{\mu} \frac{\mathrm{k}^{2}}{\varepsilon}
$$

In which $\mathrm{C} \mu=0.09$ is experimental constant. Prandtl Turbulence numbers for $\mathrm{K}$ and $\varepsilon$ respectively include, the $\sigma_{\mathrm{k}}=1.0, \quad \sigma_{\varepsilon}=1.3, \quad \mathrm{C}_{1 \varepsilon}=1.44, \mathrm{C}_{2 \varepsilon}=1092$ are constants equation $\varepsilon$. generation turbulence kinetic energy $\mathrm{G}$, in resulting average velocity gradient, is defined as follow.

$$
\mathrm{G}=\mu_{\mathrm{T}}=\left\{\frac{\partial \mathrm{u}_{\mathrm{i}}}{\partial \mathrm{x}_{\mathrm{j}}}+\frac{\partial \mathrm{u}_{\mathrm{j}}}{\partial \mathrm{x}_{\mathrm{i}}}\right\} \frac{\partial \mathrm{u}_{\mathrm{i}}}{\partial \mathrm{x}_{\mathrm{j}}}
$$

\subsection{VOLUME OF FLUID MODEL (VOF)}

Volume of Fluid model (VOF) by Hirt and Nichols was suggested in 1981. That to determine common surface of two fluid phases has been considered in many hydrodynamic issues. also In The hydraulic phenomena,free surface flow, is very important in solution of flow field. Various methods are used in determine the free surface, That,are different relative to prevailing view of solving the flow field. In VOF method, for each a component volume of cell is solved a differential equation, which ultimately amount component volume of fluid is determined in each cell. In flow field with the fixed network, is determined determine free surface based on the view O'Leary toward flow. Equations formulation are basis on fluid volume models (VOF), based on the fact that two or more fluid phases that together they are not mixed together. The purpose of this model is to find, the interface between phases in different parts of domain. Although the basis of this theoretical model, is polyphase flows, but, VOF model is not a polyphase model. For example, in the case of two-phase gas (air) and water, a series momentum equations between the two phases is be shared. For each fluid phase is added to the modeI in fact, one variable, into Solving process and this variable, is the component volume of fluid in each of calculated cells, So that the sum volume of fluid component in a cell is equal to the unit. In the case two phases water and air component volume of fluid water or air can be considered as a added variable.if $a_{w}$ is a component volume of water. Then, component volume of air, is equal to.

$$
\mathrm{a}_{\mathrm{a}}=1-a_{\mathrm{w}}
$$

In addition, field of existing variables and their characteristics is divided between existing phases and as long as the component volume of phase, is known at different points, whit an volumetric average value, is described. Thus, the issue variables and their characteristics in each of computational cells, both can be representative of one of phases, and both can be representative a mixture of phases That this Subject, is related to values phase 
volume component. In other words and in the general case, if, the component volume of q-th phase existing in computational cell, is shown by $\alpha_{\mathrm{q}}$, then is represented following three modes.

- $\quad \alpha_{\mathrm{q}}=0$, corresponding to the case, that cell is lack the q-th fluid.

- $\quad \alpha_{\mathrm{q}}=1$, corresponding to the case, that computational cell, is full the q-th fluid.

- $\quad 0<\alpha_{\mathrm{q}}<1$, corresponding to the case ,that computational cell, is, containing surface subscription between the q-th fluid, with one or more other fluids.

\subsection{BOUNDARY CONDITIONS GRIDDED OF MODELS \\ III. ISSUE DESCRIPTION AND NUMERICAL SOLUTION}

In this research, For mesh Models made, are used the regular mesh with triangular elements. In Figure (3), we can see how the mesh and Boundary conditions used for the models stepped spillway models. For numerical analysis, has been used the FLUENT software, that works based on finite volume method. in Figure (3). in Fig (3), (A): the velocity inlet boundary condition, (B): the air inlet boundary conditions, that form zero pressure, (C): the air inlet boundary conditions, that form zero pressure, (D) : the walls boundary conditions, (F): is the outlet boundary conditions, which is considered to be zero pressure and, (E): the surface flow profile initial conditions, is in stepped spillway.

\subsection{THE GEOMETRIC CHARACTERISTICS OF MODELS}

In total,for the stepped spillways, has been considered, 2 Group Model With 5th and 10th steps, That each group has been considered for the three Discharge in per units width (q) $0.025,0.039,0.057(\mathrm{~m} 2 / \mathrm{s})$ and critical flow depth (yc) 0.40, 0.054,0.069 (m). In all models, is steps height, in 5 stepped models, $0.085 \mathrm{~m}$ and for models with 10 steps, steps height of 0.1722 meters. For total models, were considered spillway height, equal and $1 \mathrm{~m}$. The slope of spillway for all models is 45 degree and the spillway crest is climactic. (Table 1.)

\subsection{NuMERICAL ANALYSIS STEPPED SPILlWAY}

In Table (2) the results related to numerical analysis, is presented in each 2 groups stepped spillway (6 models). In this table, observed the types of flow and calculated the rate of energy dissipation from numerical analysis, can bee seen for each of the models. In Figures of (4), (5) and (6), can be observed, the Flow profiles formed in the models. The flow surface profiles obtained from the numerical analysis, which have surface flat almost and low curvature, is called continuous flow (Skimming Flow) and the flows, which have Deformation in the surface flow, is considered Transation Flow and the flows which have falling jet down over Steps are named nappe Flow. In Figure (7), (8) and (9), can be observed, the velocity field shaped in the models.

\subsection{COMPARISON BETWEEN THE RESULTS NUMERICAL ANALYSIS WITH EXPERIMENTAL RELATIONSHIPSHIPS:}

In tables (3), (4) and (5), respectively, Can be observed Comparison the numerical results with experimental relationshipships, of the researchers such as, Salmasi (2003), chanson (1994) and Rajartnam (1990). In this tables, which is relate to the Group 1 (with 5 steps) of the numerical analysis can be investigated to availabel errors between the numerical method and experimental method. Comparison of the numerical method shows for calculating the energy dissipation in simple stepped spillway groups one with Salmasies experimental relationships in 2003, whit three discharge per unit width $0.025,0.039$ and $0.057(\mathrm{~m} 2 / \mathrm{s})$, respectively, $1.32 \%, 1.29 \%$ and $0.79 \%$ and with chanson experimental relationships (1994),respectively, $1.76 \%$, $0.40 \%$ and $0.54 \%$ error and with Rajartnams experimental relationships (1990), respectively, $0.46 \%, 0.94 \%$ and $0.29 \%$ error and the results has suitable error, That from this Viewpoint Shows the proximity of numerical solution with experimental work.

In tables (6), (7) and (8), respectively, Can be observed Comparison the numerical results with experimental relationshipships, of the researchers such as, Salmasi (2003), chanson (1994) and Rajartnam (1990). In this tables, which is relate to the Group 2 (with 10 steps) of the numerical analysis can be investigated to availabel errors between the numerical method and experimental method. Comparison of the numerical method shows for calculating the energy dissipation in simple stepped spillway groups one with Salmasies experimental relationships in 2003, in three discharge per unit width $0.025,0.039$ and $0.057(\mathrm{~m} 2 / \mathrm{s})$, respectively, $2.29 \%, 0.20 \%$ and $0.27 \%$ and with chanson experimental relationships (1994), respectively, $1.88 \%, 1.44 \%$ and $0.97 \%$ error and with Rajartnams experimental relationships (1990), respectively, $0.13 \%$, $2.40 \%$ and $1.91 \%$ error and again the results has suitable error, That from this Viewpoint Shows the proximity of numerical solution with experimental work.

The results of numerical analysis,stepped spillways, in figure (10), (11), (12), is visible the diagram. Figure (10) shows the variation of step height in simple stepped spillway, That, by reducing steps height is reduced energy dissipation.also shows the variation step length in simple stepped spillway in which situation is fixed the number of steps and step height by reduction step length is reduced energy dissipation. Figure (11) shows the variation number of step in the simple stepped spillway by increasing the number of steps is reduced 
energy dissipation. Figure (12) shows the variation of discharge in the simple stepped spillway, that ,by increasing flow discharge is reduced energy dissipatio.

In the forms, tables and diagrams are provided to compare the results obtained from the variation of different parameters numerically and compared these changes with results obtained from empirical relations for models made, has shown that near diagrams in numerical models with experimental models, indicating nearby and agreement between the numerical model in the compared with experimental models.

\subsection{COMPARE AND DIAGNOSIS TYPE OF FLOW NUMERICAL METHOD WITH EXPERIMENTAL RELATIONSHIPS:}

In tables (9), (10) and (11), respectively, Can be observed Comparison the numerical results with experimental relationshipships, of the researchers such as, Salmasi (2003), Rajartnam (1999) and chanson (1994) for the simple stepped spillway. In this table, which is related to the groups 1 and 2 of numerical analysis, can be observed, the results of numerical methods compatible well with other the researchers methods.

In following table, (TR) representative the Transition flow, (SK) representative the Skimming flow and (NA) as agent representative is Nappe flow.

\section{CONCLUSIONS}

In this research, firstly, was checked the effective factors on energy dissipation in types of stepped spillways, by means numerical method, which in previous researches, were checked by means numerically, Then, impact of each of these factors (the number of step), rate of Discharge, height and width of the step and ...), as can be observed in the rate of energy dissipation. In this research, the results obtained from the calculation of energy dissipation and diagnosis type of flow in Types of stepped spillways, by means numerical methods were compared, by the experimental relationships. the results obtained from of this research The effective factors on energy dissipation in types of stepped spillway can help designers for design better and more economical. The results of this part of the research, are compliance with the experimental results Salmasi (1382), Chanson (1994) and Rajartnam (1990). The error percentage obtained in the calculated energy dissipation by numerical method, in the compared with the experimental relationships can be caused of the calculated water surface in the numerical model, which, is considered in relationships to calculate the energy dissipation. Therefore we can, with the more accurate measurement of calculation water surface in the numerical model or use deep water after hydraulic jump (due to the air outlet in this area) in relationships to energy dissipation, to obtained more accurate results and minimize errors.

The numerical analysis in this research ,can be reached the following results.

- According to the results obtained from the numerical models and comparison with experimental models, and their low error can be used, low cost and speed of numerical methods such as Fluent numerical model, instead of expensive testing in, hydraulic structures.

- The energy loss in the stepped spillways,is further,the smooth spillways.

- Increased Discharge over stepped spillways, causing increased velocity flow, and converting flow to the skimming flow, and ultimately, will reduce the energy dissipation.

- in the stepped spillways Increasing the number of steps (height steps reduction) when height Dam is fixed, causing the surface steps sooner to be submerged below the surface water, and resulting, Causing, is reducing energy dissipation.

- in the stepped spillways whit the Increasing height of steps, will cause the, spillways, act as vertical slope breakers, and with the creation, nappe flow, will increase energy dissipation.

- Decrease of slope, in stepped spillways, is causes increases energy dissipation.

- Increase the length of steps in a from that are fixed the height of steps and or the height of steps are equals, causes the crossing flow, larger surface (coarse), have for to contact their face, and Consequently,causes is increased of the energy dissipation.

- The results that, numerical method is present to detection type of flow in the stepped spillways, to relationships, experimental, Salmasi in 1382, Chanson in 1994, and Rajartnam in 1990 are presented, for detection type of flow is fully compliance.

\section{RESOURCES AND REFERENCES}

[1] Christodoulou, G.C, Energy dissipation on stepped spillway, Journal of Hydraulic Engineering, ASCE, Vol.119, No.5, 644-649.

[2] Chamani, M.R. and Rajaratnam, N, Jet flow on stepped spillways, Journal of Hydraulic ASCE, Engineering. Vol.120, No.2, 254-259

[3] Chamani, M.R. Rajaratnam, N, Onset of skimming flow on stepped spillways, Journal of Hydraulic Engineering. ASCE, Vol.125, No.9, 969-971 
[4] Chen, Q. Dai, G. Liu, H, Volume of fluid model for turbulence numerical simulation of stepped spillway overflow, Journal of Hydraulic Engineering, ASCE, Vol.128, No.7, 683-688.

[5] Boes, R.M. Hager, H.W. 2003, Hydraulic design of stepped spillways, Journal of Hydraulic Engineering. ASCE, Vol.129, No.9, 671- 679

[6] Chatila, J. Tabbara, M, Computational simulation of flow over stepped spillways, Journal of Computersand Structures, No.83, 2215-2224.

[7] Tabbara, M. Chatila, J. Awwad, R, Computational simulation of flow over stepped spillways, Journal of Computers and Structures, No.83, 2215-2224.

[8] Launder, BE. Spalding, D.B, Lectures in mathematical model of turbulence, Academic, London, 1972.

[9] Fluent User's Guide ,FluentInc, 2001.

[10] Salmasi. f, Hydraulic Evaluation of stepped spillways by using physical models, doctoral diss, University of shahi Chamran, ahvaz, iran, 2003.

[11] Naderi Rad. a, Evaluation of energy dissipation in stepped spillway variety simple, sloping edges and by using numerical method by software (FLUENT), MS, University of Shiraz, 1386.

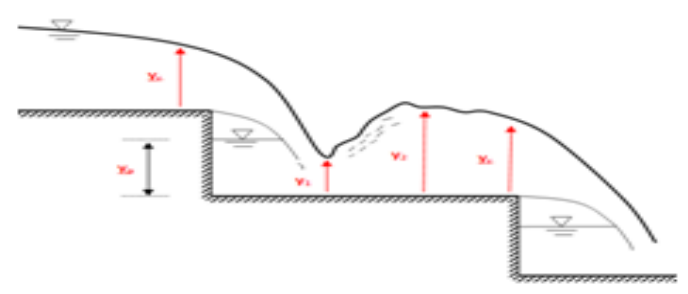

Fig 1. Nappe Flow Regime
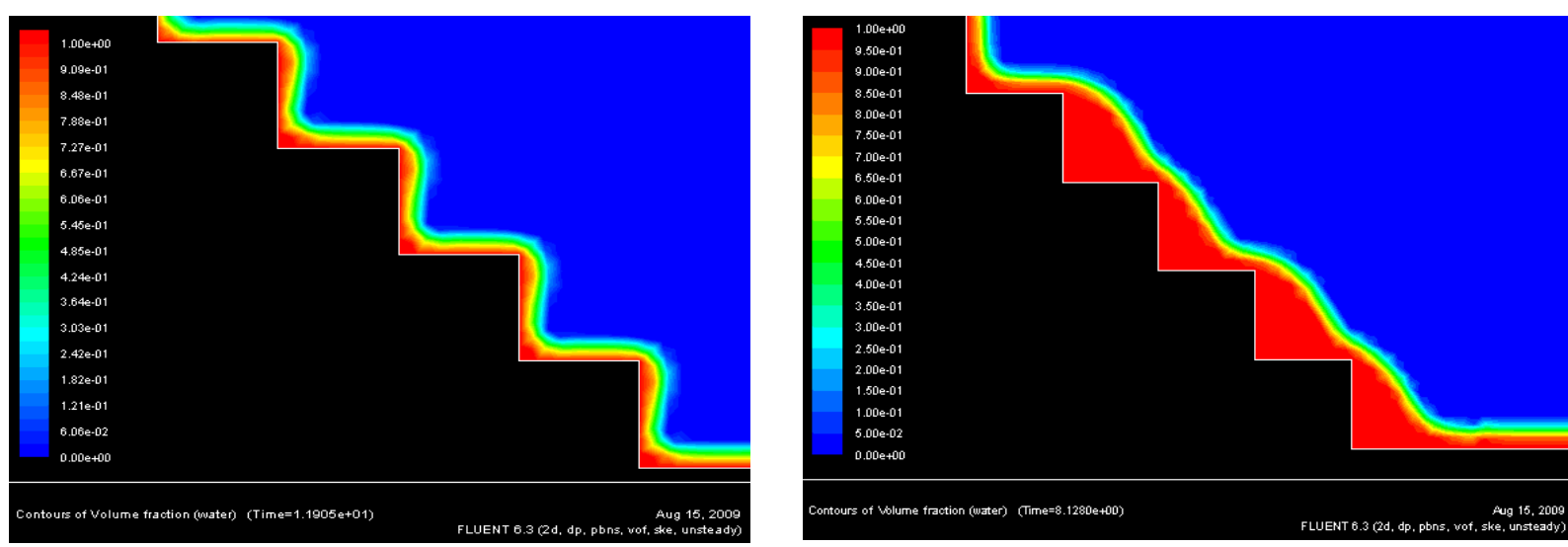

Fig 3 . the Sample mesh and boundary conditions used in the stepped spillway models

Fig 4 . nappe Flow profiles in stepped spillway model
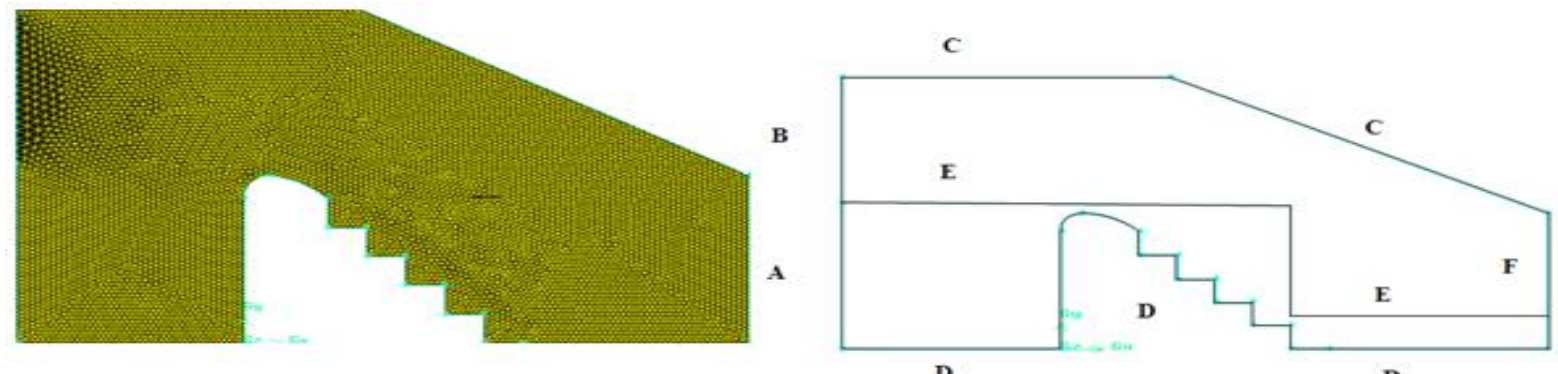

D

Fig 5 . Transation Flow profiles in stepped spillway model Fig 6 . skimming Flow profiles in stepped spillway model 

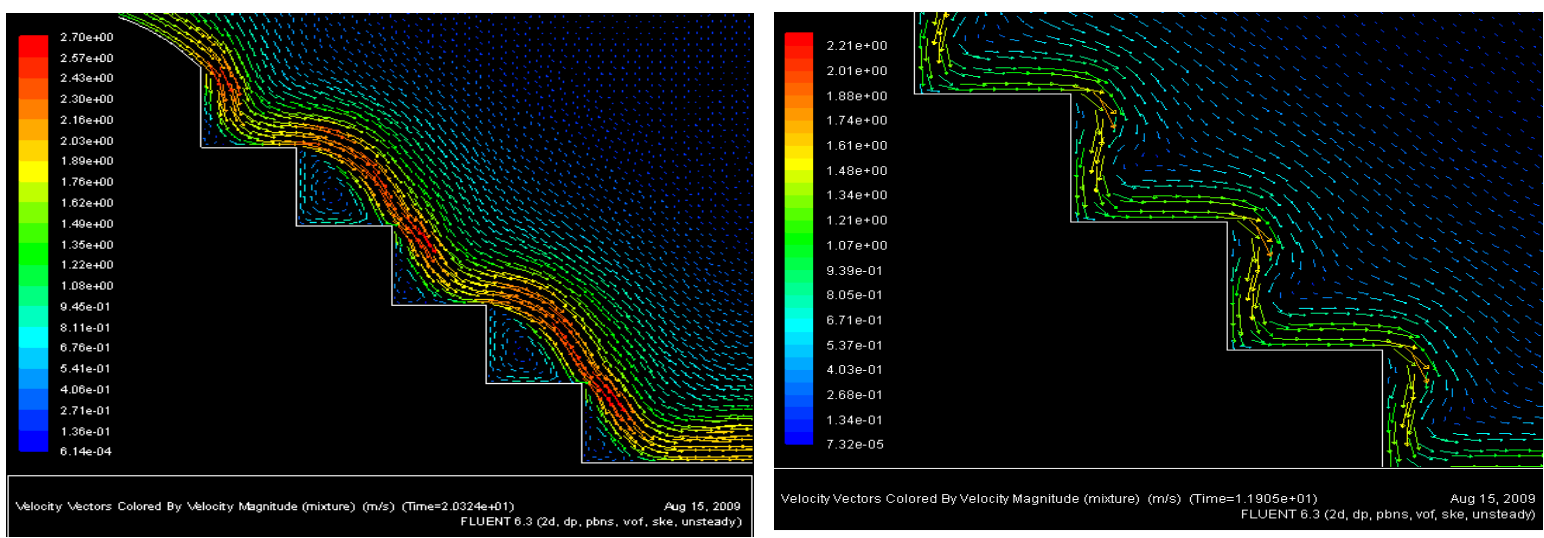

Fig 8 . velocity vectors of Transation flow in stepped spillway Fig 7 . velocity vectors of nappe flow in stepped spillway
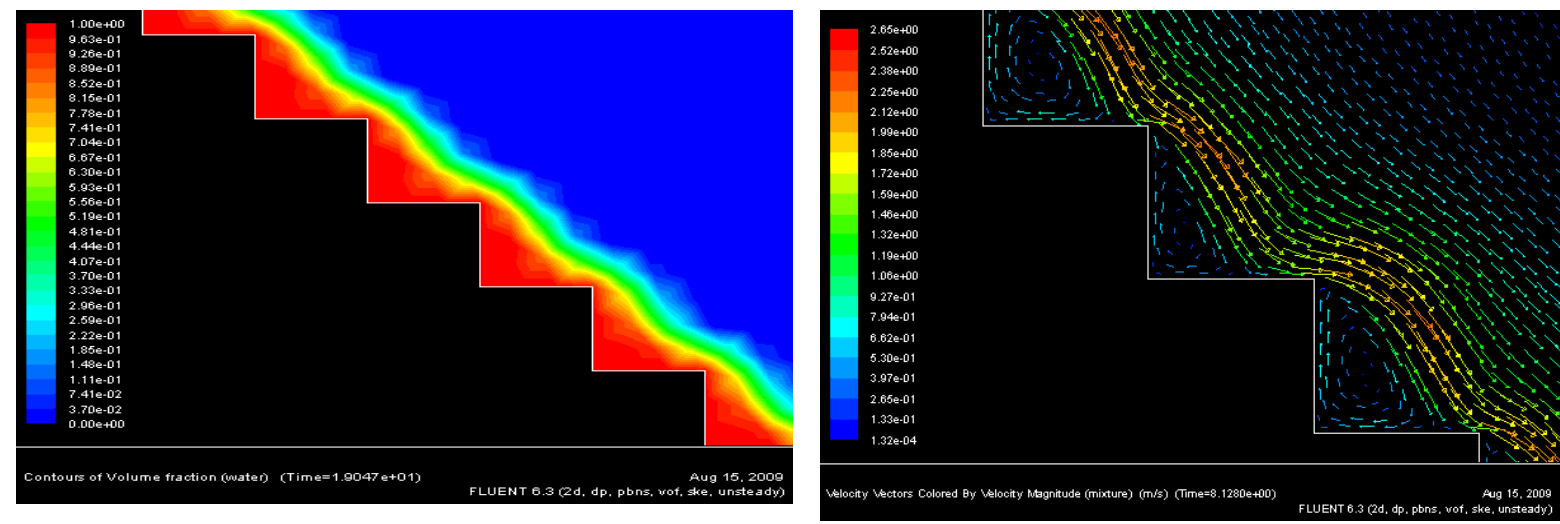

Fig 9. velocity vectors of skimming flow (Continuous) in stepped spillway model Fig 10 . Diagram, changes, of step height, in stepped spillway
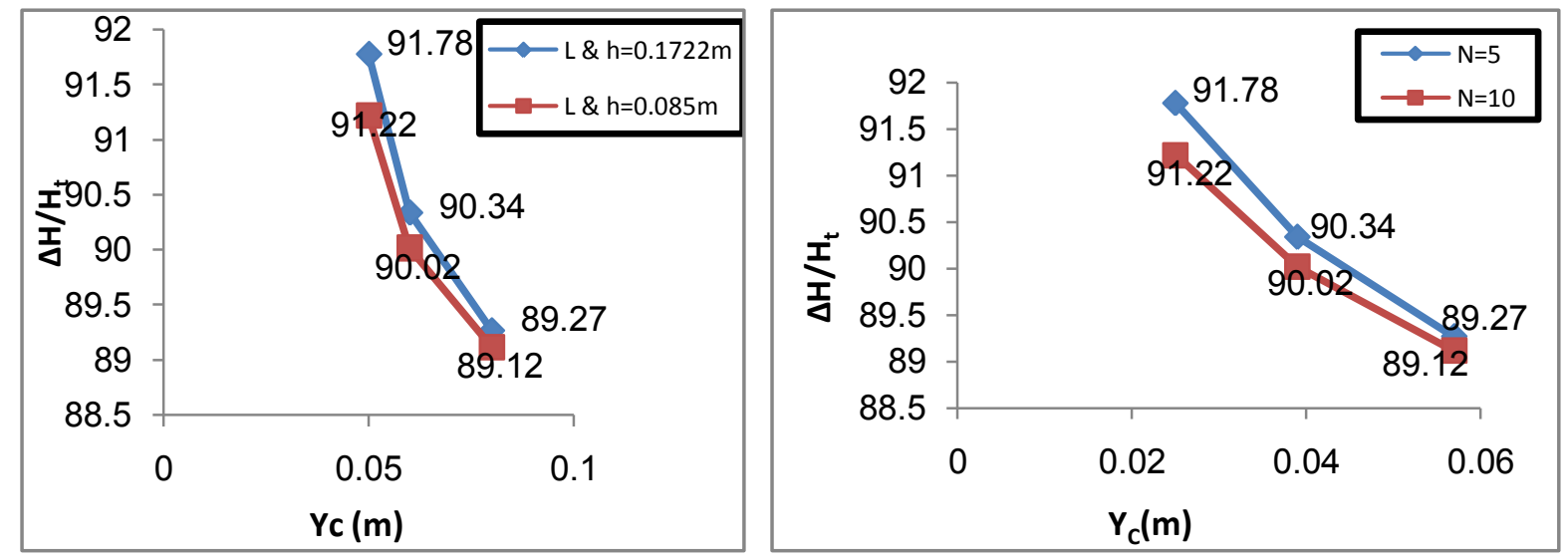

Fig 11 . Diagram, changes the number of step in and changes of step length, in simple stepped spillway stepped spillway 


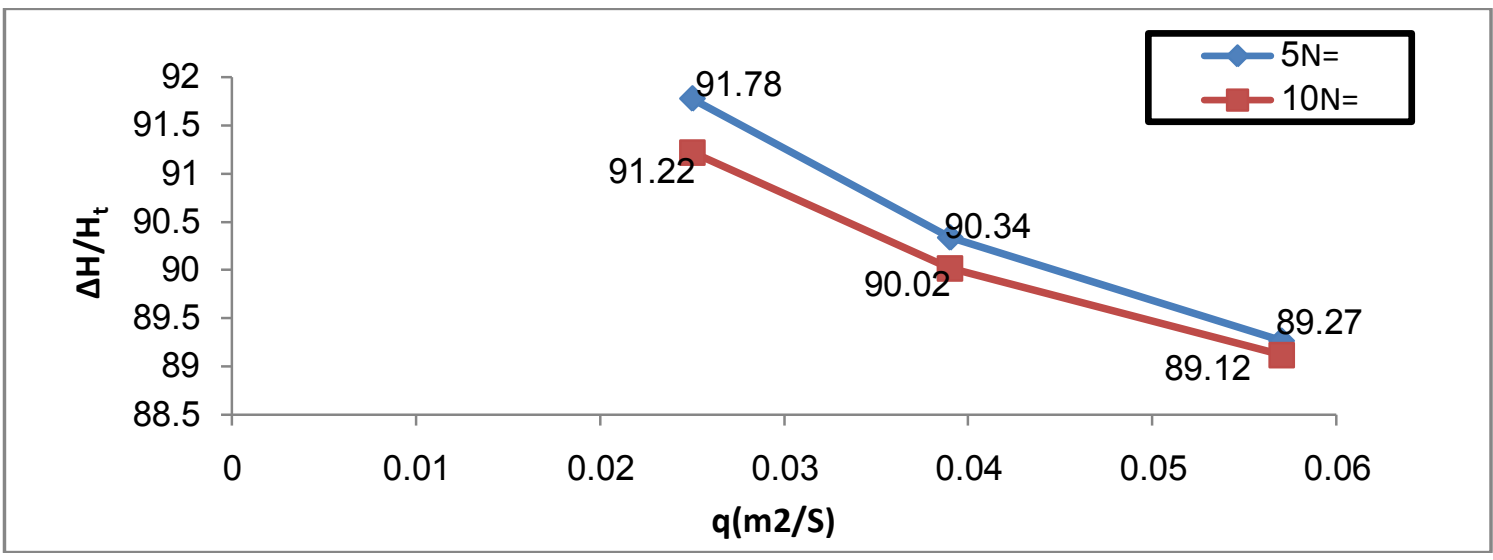

Fig 12 . Diagram, changes of discharge, in simple stepped spillway

Table 1. Specifications of geometric, stepped spillway models

\begin{tabular}{ccccccccc}
\hline Group & $\begin{array}{c}\mathrm{Q} \\
(\mathrm{m} 3 / \mathrm{s})\end{array}$ & $\begin{array}{c}\mathrm{q} \\
(\mathrm{m} 2 / \mathrm{s})\end{array}$ & $\begin{array}{c}\mathrm{yc} \\
(\mathrm{m})\end{array}$ & $\begin{array}{c}\mathrm{H} \\
(\mathrm{m})\end{array}$ & $\begin{array}{c}\mathrm{L} \\
(\mathrm{m})\end{array}$ & $\begin{array}{c}\text { Hdam } \\
(\mathrm{m})\end{array}$ & $\mathrm{N}$ & $\begin{array}{c}\text { Slope } \\
(\text { Degree })\end{array}$ \\
\hline \multirow{2}{*}{1} & 0.01236 & 0.025 & 0.040 & 0.1722 & 0.1722 & 1.00 & 5 & 45 \\
& 0.01952 & 0.039 & 0.054 & 0.1722 & 0.1722 & 1.00 & 5 & 45 \\
& 0.0282 & 0.057 & 0.069 & 0.1722 & 0.1722 & 1.00 & 5 & 45 \\
\hline \multirow{2}{*}{2} & 0.01236 & 0.025 & 0.040 & 0.085 & 0.085 & 1.00 & 10 & 45 \\
& 0.01952 & 0.039 & 0.054 & 0.085 & 0.085 & 1.00 & 10 & 45 \\
& 0.0282 & 0.057 & 0.069 & 0.085 & 0.085 & 1.00 & 10 & 45 \\
\hline
\end{tabular}

Table 2 . the Results numerical analysis of stepped spillway

\begin{tabular}{ccccccccccc}
\hline Group & $\begin{array}{c}\mathrm{Q} \\
(\mathrm{m} 3 / \mathrm{s})\end{array}$ & $\begin{array}{c}\mathrm{q} \\
(\mathrm{m} 2 / \mathrm{s})\end{array}$ & $\begin{array}{c}\mathrm{yc} \\
(\mathrm{m})\end{array}$ & $\begin{array}{c}\mathrm{h} \\
(\mathrm{m})\end{array}$ & $\begin{array}{c}\mathrm{L} \\
(\mathrm{m})\end{array}$ & $\begin{array}{c}\text { Hdam } \\
(\mathrm{m})\end{array}$ & $\mathrm{N}$ & $\begin{array}{c}\text { Type } \\
\text { of flow }\end{array}$ & $\begin{array}{c}\text { Slope } \\
(\text { Degree })\end{array}$ \\
\hline \multirow{4}{*}{1} & 0.01236 & 0.025 & 0.040 & 0.1722 & 0.1722 & 1.00 & 5 & $\mathrm{NA}$ & 91.78 & 45 \\
& 0.01952 & 0.039 & 0.054 & 0.1722 & 0.1722 & 1.00 & 5 & $\mathrm{NA}$ & 90.34 & 45 \\
& 0.0282 & 0.057 & 0.069 & 0.1722 & 0.1722 & 1.00 & 5 & $\mathrm{NA}$ & 89.22 & 45 \\
& 0.01236 & 0.025 & 0.040 & 0.085 & 0.085 & 1.00 & 10 & $\mathrm{~T}-\mathrm{S}$ & 91.22 & 45 \\
2 & 0.01952 & 0.039 & 0.054 & 0.085 & 0.085 & 1.00 & 10 & $\mathrm{~T}-\mathrm{S}$ & 90.02 & 45 \\
& 0.0282 & 0.057 & 0.069 & 0.085 & 0.085 & 1.00 & 10 & $\mathrm{~T}-\mathrm{S}$ & 89.12 & 45 \\
\hline
\end{tabular}

Table 3. Comparison of results, numerical and experimental methods, the simple stepped spillway, Group 1, with Salmasi (2003)

\begin{tabular}{cccc}
\hline critical depth flow & numerical method & salmasi (2003) & Error \\
$($ Yc) & & & $(\%)$ \\
\hline 0.04 & & 90.58 & 1.32 \\
0.054 & 91.78 & 89.19 & 1.29 \\
0.069 & 90.34 & $\mathbf{8 8 . 5 2}$ & $\mathbf{0 . 7 9}$ \\
& & & 1.13 \\
\hline
\end{tabular}


Numerical flow model stepped spillways in order to maximize energy dissipation using FLUENT

Table 4. Comparison of results, numerical and experimental methods, the simple stepped spillway, Group 1, with chanson (1994)

\begin{tabular}{|c|c|c|c|}
\hline $\begin{array}{c}\text { critical depth flow } \\
\text { (Yc) }\end{array}$ & numerical method & chanson (1994) & $\begin{array}{c}\text { Error } \\
(\%)\end{array}$ \\
\hline 0.04 & 91.78 & 90.19 & 1.76 \\
\hline 0.054 & 90.34 & 89.98 & 0.40 \\
\hline 0.069 & 89.22 & 89.70 & -0.54 \\
\hline & & Average error & 0.54 \\
\hline
\end{tabular}

Table 5. Comparison of results, numerical and experimental methods, the simple stepped spillway, Group 1, with rajartnam (1990)

\begin{tabular}{cccc}
\hline critical depth flow & numerical method & rajartnam $(1990)$ & Error \\
& & & $(\%)$ \\
\hline Yc) & & 92.20 & $\mathbf{0 . 4 6}$ \\
$\mathbf{0 . 0 4}$ & $\mathbf{9 1 . 7 8}$ & $\mathbf{8 9 . 5 0}$ & $\mathbf{0 . 9 4}$ \\
$\mathbf{0 . 0 6 9}$ & $\mathbf{9 0 . 3 4}$ & $\mathbf{8 9 . 4 8}$ & $\mathbf{- 0 . 2 9}$ \\
& & & $\mathbf{0 . 0 6}$ \\
\hline
\end{tabular}

Table 6 . Comparison of results, numerical and experimental methods, the simple stepped spillway, Group 2, with salmasi (2003)

\begin{tabular}{cccc}
\hline critical depth flow & numerical method & salmasi (2003) & Error \\
& & & $(\%)$ \\
\hline Yc) & & $\mathbf{9 3 . 3 6}$ & $\mathbf{- 2 . 2 9}$ \\
$\mathbf{0 . 0 4}$ & $\mathbf{9 1 . 2 2}$ & $\mathbf{8 9 . 8 4}$ & $\mathbf{0 . 2 0}$ \\
$\mathbf{0 . 0 5 4}$ & $\mathbf{9 0 . 0 2}$ & $\mathbf{8 9 . 3 6}$ & $\mathbf{- 0 . 2 7}$ \\
& $\mathbf{8 9 . 1 2}$ & & $\mathbf{- 0 . 4 7}$ \\
\hline
\end{tabular}

Table 7 . Comparison of results, numerical and experimental methods, the simple stepped spillway, Group 2, with chanson (1994)

\begin{tabular}{cccc}
\hline critical depth flow & numerical method & chanson (1994) & Error \\
& & & $(\%)$ \\
$($ Yc $)$ & & & $\mathbf{1 . 8 8}$ \\
$\mathbf{0 . 0 4}$ & $\mathbf{9 1 . 2 2}$ & $\mathbf{8 9 . 5 4}$ & $\mathbf{1 . 4 4}$ \\
$\mathbf{0 . 0 5 4}$ & $\mathbf{9 0 . 0 2}$ & $\mathbf{8 8 . 7 4}$ & $\mathbf{0 . 9 7}$ \\
\hline $\mathbf{0 . 0 6 9}$ & $\mathbf{8 9 . 1 2}$ & $\mathbf{8 8 . 2 6}$ & $\mathbf{1 . 4 3}$ \\
\hline
\end{tabular}

Table 8. Comparison of results, numerical and experimental methods, the simple stepped spillway, Group 2, with rajartnam (1990)

\begin{tabular}{cccc}
\hline critical depth flow & numerical method & rajartnam (1990) & Error \\
& & & $(\%)$ \\
$($ Yc $)$ & & 91.10 & 0.13 \\
$\mathbf{0 . 0 4}$ & $\mathbf{9 1 . 2 2}$ & $\mathbf{8 7 . 9 1}$ & $\mathbf{2 . 4 0}$ \\
$\mathbf{0 . 0 5 4}$ & $\mathbf{9 0 . 0 2}$ & $\mathbf{8 7 . 4 5}$ & $\mathbf{1 . 9 1}$ \\
$\mathbf{0 . 0 6 9}$ & $\mathbf{8 9 . 1 2}$ & & $\mathbf{1 . 4 8}$ \\
\hline
\end{tabular}


Numerical flow model stepped spillways in order to maximize energy dissipation using FLUENT

Table 9 . Comparison of results ,numerical method and experimental method, in simple stepped spillway, Group

\begin{tabular}{ccccc}
\hline $\begin{array}{c}\text { critical depth flow } \\
(\text { Yc) }\end{array}$ & numerical method & salmasi (2003) & $\begin{array}{c}\text { Chanson } \\
(1994)\end{array}$ & rajartnam (1990) \\
\hline $\mathbf{0 . 0 4}$ & & & NA & TR \\
$\mathbf{0 . 0 5 4}$ & NA & NA & TR & SK \\
0.069 & NA & NA & NA & SK \\
\hline
\end{tabular}

Table 10 . Comparison of results, numerical method and experimental method, in simple stepped spillway, Group 2

\begin{tabular}{ccccc}
\hline $\begin{array}{c}\text { critical depth flow } \\
(\text { Yc) }\end{array}$ & $\begin{array}{c}\text { numerical } \\
\text { method }\end{array}$ & salmasi (2003) & $\begin{array}{c}\text { Chanson } \\
(1994)\end{array}$ & rajartnam (1990) \\
\hline $\mathbf{0 . 0 4}$ & NA & NA & NA & NA \\
$\mathbf{0 . 0 5 4}$ & NA & NA & NA & NA \\
0.069 & T- Na & NA & NA & TR \\
\hline
\end{tabular}

